\section{INDIAN PALAONTOLOGY.}

THE Cieological Survey of India continues to publish well-illustrated and exhaustive memoirs on the fossil invertebrate faunas of the region with which it deals. Two more on the Himalayan Trias have lately appeared, and are of much interest for study in connection with recent work on the Triassic fossils of other areas. The first momoir (Palaeontologia Indica, ser. I5, vol. vi., No. I, 1909), on the Lower Triassic Cephalopoda from Spiti, Malla Johar, and Byans, was begun several years ago by the late A. von Krafft, who collected much of the material. It has now been revised, completed, and brought up to date by Prof. C. Diener. It begins with a synopsis of the marine Lower Triassic formations of the Himalayas, which are proved to constitute a remarkably complete series. The detailed descriptions of the fossils which follow show that at least four distinct and successive faunas occur in the rocks of the district under consideration. Of these, the lowest or earliest is perhaps the most interesting, because it seems to represent the dawn of Triassic life in the sea. It is noteworthy for the complete absence of the numerous types of Palæozoic Brachiopoda, which are the predominating element in the Permian rocks of the Salt Range and the Himalayas. Both in the Alps and in the Himalayas the Permian and Trias are connected by an uninterrupted sequence of sedimentary deposits. The second memoir, by Prof. Diener (loc. cit., No. 2), is more special, treating of the fauna, chicfly Cephalopoda, of the Iraumatocrinus Limestone of Painkhanda. He returns to a discussion of the agse of this limestone, and shows that enough of its ammonites are identical with (or closely allied to) species found in Europe to justify its correlation with the Julic horizon, or zone of Trachyceras aonoides.

Another memoir just received from the Geological Survey of India, though dated Igos, contains a valuable description of the Devonian faunas of the northern Shan States by Mr. F. R. Cowper Reed (Palaeontologia Indica, n.s., vol. ii., No. 5). The fossils are chiefly corals, bryozoa, and brachiopoda, with only few representatives of other groups, but they constitute the richest collection of Devonian age hitherto described from south-eastern Asia. Most of them were obtained from Padaukpin, and many appear to be identical with European species which characterise the lower part of the Middie Devonian. The marine faunas of Middle and Upper Devonian times prove to have been remarkably cosmopolitan, but in all cases, as at Padaukpin and other places in eastern Asia, there is also a local element giving them a special character.

\section{DUTCH METEOROLOGICAL. WORK IN THE EAST.}

(I) WV have to chronicle the issue of a new set of meteorological charts for the part of the Indian Ocean around Cape Guardafui. It is issued by the Meteorological Institute of the Netherlands to replace a set of similar charts published in 1888 which is now out of print. The observations are now sufficiently numerous to justify the subdivision of the restricted area under discussion into squares measuring $12^{\prime}$ by $12^{\prime}$, so as to bring out variations over short distances.

Special attention has been given to currents. Nearly 4000 observations, extending over the period 1888-1908, have been used, and these are all based on astronomical observations made at intervals of six or eight hours. The results are represented by "current roses," giving for each subsquare the mean velocity observed from each of sixteen directions. This method of representation gives an excellent idea of the varying nature of the currents; thus some of the roses quite near to Cape Guardafui are very nearly symmetrical stars, showing that currents from all directions may be encountered. We rather miss an indication of the number of observations used in computing each vector. Some must be based on very few observations, while others represent the mean of a considerable number 1 ( 1 Koninklijk Nederland sch Metenrnlogisch Instifuut, No. ro:.
Oceanographische en Meteorologische Waarnemingen bij. Kaap Guardafui. Pp. 38. (Amsterdam: H. G. Bom, n.d.) Prire 6.00 florins.

(2) Regenwaarnemingen in Nederlandsch-Intie. Dertigste Taargang 10u8. Deel i., Dagelijksche Regenval. Pp. vi+392. Deel ii., Uitkomsten.

NO. 2 I $2 \%$, VOL. 84$]$ of records, and we cannot help ininking that it would be useful both to the mariner and to the student to be in a position to weight the results.

The charts which follow give for each month and for each subsquare the averages for wind, pressure, temperature of the air, and temperature of the water. In the last the extraordinary low temperature of the surface water off the coast south of Cape Giuardafui during the south-ivest monsoon is well shown. In July we find a reading of $18.8^{\circ} \mathrm{C}$. $\left(65.8^{\circ} \mathrm{F}\right.$.) slightly south of Ras Hafun, while in the Gulf of Aden, slightly west of Guardafui, a subsquare has a mean temperature of $30^{\circ} \mathrm{C}$. $\left(\$ 6^{\circ} \mathrm{F}\right.$.). Nevertheless, there is a caution in the introduction against relying on low surface temperatures to give warning of the proximity of land during hazy weather, for warm water is occasionally encountered south of Guardafui.

It has been found necessary to represent the monthly results for each element on a separate chart. Our first impulse when dealing with charts of this nature is to compare the results for different elements, and for this it is very laborious to have to refer to five different charts bound in different parts of the volume. We admit that there is danger of overcrowding, even if different colours are used for different elements, but it is a great advantage to be able to survey the complete data for a month with a minimum of cross-references.

(2) The rainfall volumes for the Dutch possessions in the East Indies form the thirtieth issue of the series. The first of the two volumes for 1908 gives daily observations of rainfall for 272 places. In the second volume we have statistics of the number of rain-days, greatest rainfall in a day, and comparisons with averages, and also a discussion of the records of eight autographic gauges. The publication, especially the first volume, which gives the names of all the observers for each month separately, seems at first sight unnecessarily detailed, but in a country where the rainfall is of such great economic importance such details are necessary, and do much to ensure accuracy.

\section{PRACTICAL SPECTROSCOPY.}

$A$ NOVEL and very compact form of mounting for concave gratings is described by Mr. Albert Eagle in No. 2, vol. xxxi., of the Astrophysical Journal. Such a mounting has been erected, and found very satisfactory, in the spectroscopic laboratory of the Royal College of Science, and it is the experience obtained from this that has led to the publication of the details for general use.

In the Rowland form of mounting in general use there are serious disadvantages, the chief of which is that a large and darkened room must be devoted solely to the spectrograph when in use;..the difficulty of efficient temperacure control is also a serious one. In the new form most of the disadvantages are climinated, and no serious new ones are introduced. The whole spectrograph for a ro-foot grating is, in the new form, contained in a box i f feet 1 inch in length, 25 inches brond, and 22 inches deep, and the plates reproduced in the paper prove conclusively the ficiciency of the apparatus under the ordinary conditions of laboratory work. On a photograph of the cyanogen hand at $\lambda{ }_{3} \mathrm{SS}_{3}$, taken in the fifth order with an exposure of forty minutes, lines only 0.05 in sström are distinctly resolved. The temperature is maintained constant by lasgring the double walls of the camera tube with slag wool, and the reproduction of part of a first-order iror. spectrum, given four separate exposures of ten seconds at intervals of an hour, shows how efficient it is: this spectrum was taken without any special precautions whilst other work was proceeding in the well-lighted laboratory as usual, and yet the close pair of lines, separated by only 0.118 Angström unit, at $\lambda 4240$ is resolved. Other advantages claimed for the new mounting are its comparatively low cost, its rigidity, a slightly increased dispersion, the use of higher orders than in the Rowland mounting, and the fact that the orders on either side of the normal may be employed. Asainst these are to be set two or three apparent disadvantages, of which, at first sight, a slight departure from normality appears to be the most serious; but, as pointed out by the author, an observer always has to construct a curve of errors when reducing o'servations, and such a curve would include this slighi 